This item was submitted to Loughborough's Research Repository by the author.

Items in Figshare are protected by copyright, with all rights reserved, unless otherwise indicated.

\title{
Cyberbullying within working contexts
}

\section{PLEASE CITE THE PUBLISHED VERSION}

http://www.routledge.com/9781138730441

\section{PUBLISHER}

Routledge

\section{VERSION}

AM (Accepted Manuscript)

\section{PUBLISHER STATEMENT}

This is an Accepted Manuscript of a book chapter published by Routledge in Cyberbullying at University in International Contexts on 17 September 2018, available online: http://www.routledge.com/9781138730441.

\section{LICENCE}

CC BY-NC-ND 4.0

\section{REPOSITORY RECORD}

Coyne, lain, and Samuel Farley. 2018. "Cyberbullying Within Working Contexts". figshare. https://hdl.handle.net/2134/34078. 


\title{
Cyberbullying Within Working Contexts
}

\author{
Iain Coyne ${ }^{1}$ and Samuel Farley ${ }^{2}$ \\ 1 School of Business and Economics, Loughborough University, UK \\ 2 Leeds University Business School, Leeds University, UK
}

Comparative to the literature on traditional workplace bullying and school-based cyberbullying, systematic empirical research exploring cyberbullying within working contexts is at an embryonic stage. Scholars are directing increasing attention to this research topic, and there is no doubt that our knowledge of cyberbullying at work will expand rapidly in the near future; yet, only a limited number of studies have focused specifically on cyberbullying within university employee samples (Cassidy, Faucher, \& Jackson, 2014; Coyne et al., 2017). This chapter adopts a broader work-based perspective outlining and debating the extant literature and the implications this may have for a university workplace. The chapter commences with a brief review of workplace bullying research before focusing its attention on cyberbullying within working contexts. We follow with a discussion conceptualizing cyberbullying at work, debating its similarities with and differences from traditional workplace bullying. Next, we address evidence of cyberbullying rates and critically evaluate the measurement of this behaviour, as well as debate the impact of cyberbullying on individual and organizational well-being. We then turn our attention to understanding some of the antecedents of cyberbullying and theoretical notions of why this behaviour may occur within work settings. We conclude by outlining future areas of action. 
Over the last 30 years, the proliferation of research evidence published on traditional workplace bullying has resulted in an enhanced understanding of what the behaviour is; measurements in establishing prevalence rates; the impact on individuals and organizations; situational and individual antecedents of bullying; theoretical models explaining bullying; and, more recently, strategies to reduce workplace bullying.

Evidence is consistent in highlighting a wide variety of psychological, psychosomatic, and physiological effects in victims (see Coyne, 2011) and witnesses of workplace bullying (Hoel, Cooper, \& Faragher, 2004). Within University employee samples, investigations demonstrate consequences for victims including depression and anxiety (Björkqvist, Österman, \& Hjelt-Bäck, 1994), a greater risk of alcohol abuse (Richman, Rospenda, Flaherty, \& Freels, 2001), perceptions of shame (Lewis, 2004), and higher mental strain (Coyne et al., 2017). At an organizational level, data exist indicating increased absenteeism (Kivimaki, Elovainio, \& Vahtera, 2000), lower job satisfaction (Bowling \& Beehr, 2006), and negative perceptions of team performance (Coyne, Craig, \& Smith-Lee Chong, 2004). In UK university samples specifically, Coyne et al. (2017) found a negative relationship between the experience of traditional bullying and job satisfaction. Empirical data, which illuminates the severe negative outcomes faced by individuals and organizations resulting from workplace bullying, augment the interest in this topic area and stresses the need to find solutions to reduce this behaviour.

\section{Conceptualizing traditional workplace bullying}

Perhaps one of the first confusing features individuals face when trying to understand the concept of workplace bullying is the use of different, yet seemingly similar, terms within the 
literature. Scholars are furnished with an assortment of such mixed terms, including mobbing (Zapf \& Einarsen, 2001), abusive supervision (Tepper, 2000), workplace incivility (Pearson, Andersson, \& Porath, 2005), and social undermining (Crossley, 2009). These terms appear to represent similar behaviours, yet are defended stoutly by proponents of each concept as possessing uniquely defined characteristics. Critically, Hershcovis (2010) advocates against differentiating concepts on the basis of "unique features": wherein measurement of these concepts tends not to reflect adequately the uniqueness espoused by scholars, and empirical evidence indicates minimal differences between concepts in their relationship to outcomes.

Albeit, some disagreement exists on what bullying is; Einarsen, Hoel, Zapf, and Cooper (2003) attempted to draw the body of research together to define workplace bullying. They suggest it is:

...harassing, offending, socially excluding someone or negatively affecting someone’s work tasks. In order for the label bullying (or mobbing) to be applied to a particular activity, interaction or process it has to occur repeatedly and regularly (e.g. weekly) and over a period of time (e.g. about six months). Bullying is an escalating process in the course of which the person confronted ends up in an inferior position and becomes the target of systematic negative social acts. A conflict cannot be called bullying if the incident is an isolated event or if two parties of approximately equal 'strength' are in conflict. (p. 15)

Inherent within this definition are criteria of frequency, duration, and power imbalance—all three of which differentiate workplace bullying from other related aggressive acts. Notably, unlike 
school bullying and general aggression research, workplace bullying definitions tend not to include intent. Arguments for this approach include the difficulty in measuring intent (Einarsen, Hoel, Zapf, \& Cooper, 2011) and the possibility that perpetrators may disguise their true intentions to rationalize their behaviour to others (Samnani, 2013). Support exists on including frequency, duration, and power imbalance within workplace bullying definitions (Zapf \& Einarsen, 2001); however, Rayner and Cooper (2006) argue how persistency allows a perpetrator to rationalize a one-off negative act as something that is not bullying. Further, Saunders, Huynh, and Goodman-Delahunty (2007) illustrate differences between academic definitions of bullying and how the concept is conceptualized by its practitioners.

\section{The extent of traditional bullying}

Organizational and national surveys have provided stakeholders with an indication of the extent of workplace bullying. Chronologically, rates of those experiencing bullying that were reported include 8.8\% in Finland (Salin, 2001), 10.6\% in the UK (Hoel, Cooper, \& Faragher, 2001), and $28 \%$ in the US (Lutgen-Sandvik, Tracy, \& Alberts, 2007). More recently, a meta-analysis across 86 studies by Nielsen, Matthiesen, and Einarsen (2010) illustrates a mean prevalence rate of $14.6 \%$. In relation to university employees specifically, data show prevalence rates of $30-45 \%$ (depending on gender) (Björkqvist et al., 1994); 23\% (Spratlen, 1995); and 6.2\% (Einarsen \& Skogstad, 1996).

We could argue that the plethora of survey data provides a clear indication that bullying pervades the workplace worldwide. The difficulty is in answering the question "to what extent"? As shown, bullying rates vary widely across studies and countries. While the meta-analysis offers a 
synopsis of existing data, it is not evident what the actual level of bullying is. Critics have pointed to problems in methodology within survey research (Cowie, Naylor, Rivers, Smith, \& Pereira, 2002), including variability in the timeframe adopted for bullying (e.g. at least 6 months, over the year, or ever in career) and the lack of verification for self-reported bullying exposure. Additionally, the method used to establish victim status moderates the bullying rates recorded (Coyne, Smith-Lee Chong, Seigne, \& Randall, 2003; Nielsen et al., 2010). Coyne et al. identify different victim rates (ranging from 3.9\% to 39.6\%) that depend on whether a definition of selfreport, peer-report, or a combination of self-report and peer-report was used to classify one's victim status. Nielsen et al. emphasize variability of prevalence rates for a self-labelling approach using a definition (11.3\%), self-labelling without a definition (18.1\%), and a behaviour-based scale (14.8\%).

Currently, no definitive guidance exists that advocates a specific way to assess bullying rates. Researchers have started to adopt a combination of self-reporting to a definition with behaviourbased scales as the default method for assessing prevalence rates. Additionally, support for the latent class cluster analysis methodology, which is more complex, has also been provided (Nielsen et al., 2009).

\section{Antecedents of workplace bullying}

Research on workplace bullying antecedents has focused principally on organizational factors that promote workplace bullying. Evidence has emerged indicating that organizations characterized as stressful (Hauge, Skogstad, \& Einarsen, 2007), politicized (Salin, 2003), going through change (Harvey, Heames, Richey, \& Leonard, 2006), and with poor leadership (Hoel, 
Glasø, Hetland, Cooper, \& Einarsen, 2010) are likely to experience heightened levels of bullying. Modelling these factors, Salin (2003) suggests that for bullying to occur in an organization there needs to be an initial trigger event: something which allows the bullying to evolve (e.g. organizational change), a motivating process allowing a rationale for the behaviour (e.g. competition), and conditions that facilitate bullying (e.g. poor management). In commenting on research discussing bullying among university students, Coyne (2016) suggests Salin's model may explain university bullying as:

the transition (change) to university...provides the trigger for bullying to evolve and the competitive environment...which normalizes abusive behaviour...provides the motivation to engage in bullying. When these are coupled with a lack of clear policies on bullying and power differentials..., you have the right environment for bullying to occur. (p. 204)

By comparison, individual-level explanations have received less attention, with some dismissing their usefulness for understanding workplace bullying. However, other researchers posit that disposition may help us understand the likely targets of bullying — based on the extent of their vulnerability or provocative nature (Coyne, Seigne, \& Randall, 2000). Additionally, perpetrators of bullying have been hypothesized as possessing inflated self-esteem, low empathy, and a heightened need for power (Zapf \& Einarsen, 2003).

Theoretically, bullying specific models have attempted to capture both individual and organizational characteristics as antecedents of bullying (e.g. Bowling \& Beehr, 2006; Einarsen et al., 2003). Other scholars have focused on bullying from a conflict perspective (Strandmark \& 
Hallberg, 2007) or drawn on existing psychological models on job characteristics (Notelaers, Witte, \& Einarsen, 2010), fairness perceptions (Parzefall \& Salin, 2010), and job demands/resources (Baillien, De Cuyper, \& De Witte, 2011). Although, there is still some way to go in testing the robustness of theoretical models explaining workplace bullying, these relatively recent advances are providing fruitful areas of future research.

\section{Conceptualizing cyberbullying within working contexts}

Empirical research on cyberbullying at work may be viewed as the younger sibling of traditional workplace bullying research—albeit one which is at the beginning of its growth spurt. We know comparatively little about this phenomenon in working contexts and, as a result, researchers have tended to cogitate about it: using ideas gleaned from traditional workplace bullying and/or cyberbullying among children/adolescents. Not surprisingly, current thinking is dominated by existing ideas in these other domains; yet, more surprisingly, similar issues and concerns raised in traditional bullying research afflict this area (e.g. differing definitions and debates about essential defining criteria).

Table 1 highlights a number of definitions of workplace cyberbullying and related concepts. Mirroring the traditional bullying literature, we see a variety of concepts promoted with some similarities and some "unique differences”. The majority of the definitions (e.g. Farley, Coyne, Axtell, \& Sprigg, 2016; Lim \& Teo, 2009; Weatherbee \& Kelloway, 2006) closely reflect their offline equivalent counterparts, with the addition of a technological component; others (e.g. Whitty \& Carr, 2006; Willard, 2007) promote technologically-specific concepts; while Vranjes, 
Baillien, Vandebosch, Erreygers and De Witte (2017) suggest both a similar and technologicallyspecific feature to the behaviour.

Table 1. Definitions of cyberbullying at work and related concepts should be placed near here Firstly, these differences add another level of complexity to what Hershcovis (2010) would refer to as an "abundance of overlapping constructs” (p. 499). Now, not only do we have to contend with whether incivility, aggression, and bullying are similar or different, we also need to take the online/offline component into consideration. Coyne et al. (2017) argue that as workplace cyberbullying involves frequency, is focused on high-intensity behaviours, and tends not to consider organizational outsiders; it differs conceptually from cyber-aggression and cyberincivility. However, this position is exactly the criticism Hershcovis levels at offline "aggression" research.

Secondly, the different definitions echo the current debate on whether workplace cyberbullying is simply bullying using technology (Coyne et al., 2017) or whether it is conceptually distinct from offline bullying. In this latter respect, Vranjes et al. (2017) posit specific characteristics of cyberbullying which support the conceptually-distinct hypothesis:

- Communication online is less rich as a result of a lack of non-verbal cues. Consequently, perpetrators are less aware of their impact on others.

- Online communication allows for anonymity and reduces the victim's control over the behaviour.

- Cyberbullying blurs the public/private boundary, becoming intrusive and restricting a victim's ability to escape. 
- The power imbalance derives more from technical power.

- The volume and speed of the abuse (viral reach) is increased when the behaviour is online.

Our contention is that while we acknowledge and agree there are contextual features to workplace cyberbullying not seen in traditional bullying, these features do not change the conceptualization of the concept (bullying is still bullying); rather, they may help to explain why people engage in the behaviour and/or the extent of impact on the target. This is perhaps best illustrated by discussing the definitional criteria of frequency, duration, and power imbalance seen in offline bullying definitions.

Traditionally, the frequency and duration component of bullying refers to the same person regularly experiencing negative behaviour over a long period of time. What constitutes repetition in the virtual environment is more ambiguous, especially when considering a single online act, shared in the public domain that can be viewed repeatedly by a broad audience-which may or may not be shared by the initial perpetrator. Nevertheless, while not conforming strictly to original ideas around frequency and duration, the victim will still regularly experience the behaviour over a prolonged period of time: they could even encounter the cyberbullying for longer (due to their inability to escape) and more frequently (the viral reach of the act). A second issue relating to repetition is the co-occurrence of online and offline bullying behaviour. Schoolbased (Sticca, Ruggieri, Alsaker, \& Perren, 2013) and work-related research (Coyne et al., 2017) has identified relationships between experiencing offline bullying and cyberbullying. Cooccurrence of both behaviours raises the issue of whether a respondent is experiencing 
cyberbullying or whether they are actually facing regular bullying (which has started to manifest in technological form). In the latter case, one could claim that the movement across media is indicative of frequency and duration.

Elements of power imbalance may differ when comparing cyberbullying to traditional bullying. Cyberbullying victims are potentially in a stronger position, as they can terminate negative interactions more easily by not responding to messages (Wolak, Mitchell, \& Finkelhor, 2007). However, Heatherington and Coyne (2014) argue that a victim’s perceived lack of power, rather than the bully's possession of it, characterizes the power differential in the virtual environment. We suggest that Vranjes et al.'s (2017) position of cyberbullying being conceptually different from offline bullying still falls under the remit of power differential—albeit extending our perception of what power is:

- Due to the spread of technology and the lack of boundaries within online communication, employees can be subjected to cyberbullying in their own homes, which may heighten feelings of powerlessness.

- Technological ability by the perpetrator or limited technology ability by the target can result in victim perceptions of powerlessness, as they are unable to force a perpetrator to remove abusive material or cannot influence what others write about them.

- Anonymity can increase uncertainty, as victims do not know the perpetrators—or even whether there is more than one perpetrator — thereby creating a feeling of powerlessness. 
At the beginning of this section, we expressed surprise that similar concerns levelled at traditional workplace bullying seem to permeate the research on workplace cyberbullying. The debate on what the concept is — and whether it is different to its online counterpart-perhaps illustrates these concerns clearly. Ideally, as the research evidence matures, researchers and practitioners will reach a level of consensus on how to conceptualize this form of interpersonal abusive behaviour.

\section{Types, rates, and impact of workplace cyberbullying}

Recent research has begun to unearth behaviours that may occur during workplace cyberbullying situations. Behaviours experienced by employees include anonymous abusive emails sent to everyone within an organization, negative public posts uploaded on social networking websites (D’Cruz \& Noronha, 2013), not receiving responses to emails or text messages, and being withheld necessary work-related information (Forssell, 2016). Examples reported by Human Resource (HR) professionals include employees posting inappropriate comments about their colleagues on the internet, distributing jokes via work email, and cyberstalking after an office romance had broken down (West, Foster, Levin, Edmison, \& Robibero, 2014).

The limited evidence in working populations to date for cyberbullying has shown rates in the UK of 9.2\% (Baruch, 2005), in the US/Canada of 9\% (Ford 2013), 10.7\% in Australia (Privitera \& Campbell, 2009), 2.8\% in New Zealand (Gardner et al., 2016) and 9.7\% in Sweden (Forssell, 2016). Within a university context, Giumetti, McKibben, Hatfield, Schroeder, and Kowalski (2012) reported 26\% of a sample of US university employees had experienced cyber-incivility, and Cassidy et al. (2014) reported rates of 17\% among Canadian university faculty. Across three 
different UK university employee samples, Coyne et al. (2017) detailed cyberbullying victim rates between $13.6 \%$ and $20.8 \%$.

At this juncture, one almost experiences a sense of déjà-vu observing the variety of prevalence rates for bullying at work. The variation apparent in the prevalence of cyberbullying may be due to existing cyberbullying measures being either too narrow in scope, focusing only on one medium such as email (Baruch); assessing constructs such as cyber-aggression (Ford) or cyberincivility (Guimetti et al.); or using an adapted version of the Negative Acts Questionnaire (NAQ) for use in cyber-contexts (Coyne et al.; Forssell). Different methodologies and different categorization approaches create the pattern of victim rates seen above. It is only very recently that a specific workplace cyberbullying measure (WCM) has been developed and validated (Farley et al., 2016), which may provide a metric for assessing victim and target rates of cyberbullying at work-including universities. As with traditional bullying, we may see the norm being the use of the WCM, with an additional self-reported item added, to assess victim rates of cyberbullying at work.

Paralleling traditional bullying research, evidence to date reveals experiencing cyberbullying has negative implications for both individuals and organizations. Cross-sectional investigations have shown relationships between cyberbullying, anxiety, and an intention to leave one's workplace (Baruch, 2005); general well-being and fear of future harassment (Ford, 2013); perceived stress and low optimism (Snyman \& Loh, 2015); and mental strain and job dissatisfaction (Farley, Coyne, Sprigg, Axtell, \& Subramanian, 2015). University-specific studies on cyber-incivility have shown correlations with general job stress and burnout (Giumetti et al., 2012), as well as on 
cyberbullying with negative emotion, mental strain, perceived injustice, and job dissatisfaction (Coyne et al., 2017). Indeed, in this latter study, the authors hypothesized that the "unique features" of cyberbullying (espoused earlier) may result in more severe outcomes when compared to traditional bullying; they also provide data to show the strength of relationship between cyberbullying experience, mental strain, and job dissatisfaction was stronger than for offline bullying.

\section{Antecedents of and theoretical approaches to cyberbullying within work}

Expected within a developing research area, knowledge on the antecedents of workplace cyberbullying is sparse. Gardner et al. (2016) offer some initial results from a two-wave study: finding significant correlations between poor physical health, low organizational support, and low effective organizational strategies when first experiencing cyberbullying and then again at three months later. If we concur with the view that cyberbullying within working contexts is conceptually similar to offline bullying, then researchers have a ready-made compendium of possible antecedents (e.g. change, competition, poor leadership, etc.) from an organizational and individual level, which could be considered within cyberbullying research. Using Salin’s (2003) model, researchers should identify the precipitating, motivating, and facilitating factors of workplace cyberbullying. Currently, however, there is limited research focused on directly mapping offline workplace bullying antecedents to cyberbullying contexts. The question is, then, "where do we look for possible explanations of cyberbullying within working contexts"? Theoretically, there are a number of avenues we can follow.

\section{Theories of computer-mediated communication.}


There is a vast literature on computer-mediated communication (CMC) which may help identify why people engage in or experience cyberbullying behaviour.

\section{Reduced social cues.}

Firstly, the reduced cues hypothesis (Daft, Lengel, \& Trevino, 1987; Kock, 2004) suggests CMC methods possess fewer social, contextual, and verbal cues; are lower in media richness and media naturalness; and can result in individuals being less present and more anonymous - a state described as “deindividuation”. In relation to cyberbullying, it may be more likely for people communicating virtually to misinterpret messages as cyberbullying acts. More misunderstandings occur during online communication than in person (Byron, 2008), which may lead individuals to mistakenly perceive themselves as victims of cyberbullying, even when the sender meant no ill-intent.

\section{Deindividuation.}

The deindividuation effect of CMC could also help explain cyberbullying. Computer-mediated communication is often characterized by feelings of anonymity, making people less sensitive to the thoughts and feelings of others, and causing a disinhibition effect (Siegel, Dubrovsky, Kiesler, \& Mcguire, 1986). The outcome of this effect can be benign or toxic (Suler, 2004), in which case communication becomes harsher and more abusive. Therefore—because people become absorbed in immediate communication cues, rather than focusing on self and others (Siegel et al.)— they become submerged into their technology, leading to a loss of identity and uninhibited behaviour—such as cyberbullying. 
The Social Identity model of De-individuation Effects (SIDE) (Spears \& Lea, 1994) argues that, in the absence of personal communication cues, individuals shift their attention away from interpersonal differences to focus on a common group identity, as characterized by group norms. According to SIDE, new group members accept these norms through deindividuation. Research has identified that norms of CMC are confined to the boundaries of a group-and that groups vary in the number of requests, reactions, humor, emotion, and personal revelations they deploy (Postmes, Spears, \& Lea, 2000). Group norms have implications when a newcomer joins a group, as their communication may be perceived as rude or aggressive (and vice versa), which may spark conflict and lead to cyberbullying.

Taken together, these theories provide a lens for understanding communication in the virtual environment, and how this communication (or lack of communication) promotes cyberbullying. In particular, these theories outline how aspects of online communication differ from face-to-face communication, as well as how these differences-in terms of lack of cues, misinterpretation of communication, deindividuation, disinhibition, and social identity—may result in cyberbullying behaviour.

\section{Psychological theories of cyberbullying.}

Currently, only a small number of researchers have used models encompassing features of existing bullying theories (e.g. stress, emotions, and fairness perceptions) to help explain workplace cyberbullying.

\section{Dysempowerment theory.}


Focused on university employee samples in the UK, Coyne et al. (2017) apply dysempowerment theory (Kane \& Montgomery, 1998) to explain how cyberbullying may lead to individual mental strain and job dissatisfaction. Dysempowerment theory posits an employee appraises a “polluting” work event as a violation of his/her dignity (fairness perception), which results in a perception of subjective stress_-leading to negative affect (emotion) and, in turn, disrupts the employee's attitudes and behaviour at work. The greater the volume of polluting acts perceived by an employee, the stronger the potential for dysempowerment. Therefore, dysempowerment theory could explain cyberbullying as a situation in which a target of workplace cyberbullying may perceive a series of events as a violation of their dignity (or as something unfair), exhibiting a negative affective response that impacts on their mental well-being and job attitudes. These results indicate a mediating effect of negative emotion on the relationship between the experience of cyberbullying, mental strain, and job dissatisfaction. However, data suggests interpersonal justice and negative affect were two separate routes, through which cyberbullying may have its own effect: with negative emotion exhibiting a stronger effect on mental strain than job dissatisfaction, and justice only mediating the relationship between cyberbullying and job dissatisfaction.

Farley et al. (2015) go one stage further in their theories: combining dysempowerment theory with the attributional model of workplace harassment (Bowling \& Beehr, 2006). They suggest that attribution of blame for the "polluting” event of cyberbullying impacts perceptions of violations to one’s dignity and influence negative emotional responses. Findings indicate negative emotion mediated the relationship between self-blame for a cyberbullying act and mental strain, whereas interactional injustice mediated the association between blaming the 
perpetrator and job dissatisfaction. Attributions of blame potentially go some way in explaining the different paths seen in the Coyne et al. study.

\section{Emotion Reaction Model.}

Offering a perspective on why people experience and/or engage in cyberbullying (rather than modelling the impact of cyberbullying), Vranjes et al. (2017) posit the moderation-mediation Emotion Reaction Model. They theorize that work-related stressors at the job (e.g. role conflict), team (interpersonal conflict), and organization levels (e.g. change) relate to experience and engagement in cyberbullying behaviour at work. This stressor-strain relationship is mediated by discrete emotions of anger, fear, and sadness—-with anger promoting the engagement in cyberbullying (via a retaliation process) and fear/sadness promoting the experience of cyberbullying (via a powerlessness process). Additionally, control appraisal is espoused to moderate the relationship between stressors and emotions. When stressors are seen to be under an individual's control, anger arises; comparatively, fear and sadness arise when work stressors are attributed to situational factors. Emotional regulation is also identified as a moderator, but with different impacts, depending on the type of strategy adopted. Reappraisal buffers the effect of stressors on emotions, whereas suppression increases the relationship of emotions to the experience or engagement of cyberbullying.

When considering the lifespan of its research, it is a strength that the development and testing of theoretical ideas related to cyberbullying within working contexts has arisen at such an early stage. Both the Coyne et al. and Vranjes et al. approaches have foundations within stress theories (similar to offline bullying models), and also provide insights as to the why and consequences of 
cyberbullying in workplace settings. There is no reason to believe that a university context will be any different to other working contexts in terms of job, team, and organizational stressors—or else perceptions of what is/is not unfair behaviour, perceptions of blame, and emotional reactions.

\section{Conclusion}

The evidence base for offline workplace bullying is extensive. Increasingly, it becomes more and more robust in terms of its theory-driven nature and methodological approaches. Cyberbullying research within working contexts is limited by comparison, but it is comforting to know that scholars are increasingly becoming aware of and interested in this concept—as well as notions of how cyberbullying emerges. Concerns to its impact have evolved much earlier on in the lifespan of a research agenda.

Going forward, a number of action points can be offered:

1. Consensus on whether cyberbullying is different to or the same as offline bullying should be reached. Meta-analytic approaches akin to Herschcovis (2010) will allow us to test if there are empirical differences between concepts in their relationship to antecedents and outcomes, and should establish support for one position or the other.

2. Use and validation of specific workplace cyberbullying measures - as well as approaches in classifying victim status—should exist, as they allow comparisons to be made across organizations, sectors, and countries. Perhaps aligning to the approach adopted within offline bullying is the optimal solution. 
3. Further testing and (where appropriate) the updating of models offered to explain cyberbullying at work should be implemented. It would be useful to consider including ideas from the CMC literature within current psychological models, as they may help to explain why people perceive messages as a violation of dignity—or why disinhibited actions result from stressors and emotions.

4. There should be a consideration of other roles within the cyberbullying situation. In parallel with offline workplace bullying research, the focus has tended to be at level of the victim (although Vranjes’s model does also consider the perpetrator). Witnesses/bystanders have, to date, been largely neglected in this process, with limited research suggesting —unlike offline bullying—witnesses of cyberbullying do not exhibit negative outcomes (Coyne et al., 2017).

5. Lastly, identification and the development of evidence-based interventions could be put in place to reduce cyberbullying at work (see Farley and Coyne, this volume). 


\section{Table 1}

Definitions of cyberbullying at work and related concepts

\begin{tabular}{lll}
\hline Authors & Concept & Definition
\end{tabular}

Whitty \& Carr

(2006, p. 237-238)

\section{Cyber-harassment}

“...obscene or hate email that threatens or frightens, or emails that contain offensive content, such as sexist or racist material...this material can be sent by people... (either known or unknown to the person)”

Weatherbee \&

Cyberaggression

Kelloway (2006, p.

Willard (2007, p. 5) Flaming

Lim \& Teo (2009, p. Cyber incivility 419) “aggression expressed in a communication between two or more people using ICTs, wherein at least one person in the communication aggresses against another in order to effect harm"

"heated, short lived argument that occurs between two or more protagonists.”

"communicative behavior exhibited in computermediated interactions that violate workplace norms of mutual respect” 


\begin{tabular}{lll}
\hline Authors & Concept & Definition
\end{tabular}

\begin{tabular}{lll}
\hline Zhang \& Leidner & Workplace & "instances where an employee is systematically \\
(2014, p. 2) & cyberbullying & exposed to repeated negative treatment from \\
& supervisors, colleagues or subordinates by electronic \\
& forms of contact over a long period of time, in a \\
& situation in which the perpetrator has more power \\
& than the target"
\end{tabular}

Farley et al. (2016, Workplace "a situation where over time, an individual is p. 295) cyberbullying repeatedly subjected to perceived negative acts conducted through technology (e.g. phone, email, web sites, social media) which are related to their work context. In this situation the target of workplace cyberbullying has difficulty defending him or herself against these actions"

Forssell (2016, p. Workplace $\quad$ "Negative acts carried out by a group or an 457) cyberbullying individual using digital media. The acts are carried out repeatedly and over time against a victim who cannot easily defend him or herself. Online harassment can be expressed by offensive or rude text messages, email, or someone posting unpleasant 


\begin{tabular}{lll}
\hline Authors & Concept & Definition
\end{tabular}

and offensive information (picture, videos, or text) on the Internet"

Vranjes et al. (2017, Workplace

p. 326) cyberbullying "all negative behavior stemming from the work

context and occurring through the use of ICTs, which is either (a) carried out repeatedly and over a period of time or (b) conducted at least once but forms and intrusion into someone's private life, (potentially) exposing it to a wide online audience. This behavior leaves the target feeling helpless and unable to defend" 


\section{References}

Baillien, E., De Cuyper, N., \& De Witte, H. (2011). Job autonomy and workload as antecedents of workplace bullying: A two-wave test of Karasek’s Job Demand Control Model for targets and perpetrators. Journal of Occupational and Organizational Psychology, 84(1), 191-208.

Baruch, Y. (2005). Bullying on the net: adverse behavior on e-mail and its impact. Information \& Management, 42(2), 361-371.

Björkqvist, K., Österman, K., \& Hjelt-Bäck, M. (1994). Aggression among university employees. Aggressive Behavior, 20, 173-184.

Bowling, N. A., \& Beehr, T. A. (2006). Workplace harassment from the victim's perspective : A theoretical model and meta-analysis. Journal of Applied Psychology, 91(5), 998-1012.

Byron, K. (2008). Carrying too heavy a load? The communication and miscommunication of emotion by email. Academy of Management Review, 33(2), 309-327.

Cassidy, W., Faucher, C., \& Jackson, M. (2014). The dark side of the ivory tower: Cyberbullying of university faculty and teaching personnel. Alberta Journal of Educational Research, 60(2), 279-299.

Cowie, H., Naylor, P., Rivers, I., Smith, P. K., \& Pereira, B. (2002). Measuring workplace bullying. Agggression and Violent Behavior, 7, 33-51.

Coyne, I. (2011). Bullying in the workplace. In C. P. Monks \& I. Coyne (Eds.), Bullying in Different Contexts (pp. 157-184). Cambridge: Cambridge University Press.

Coyne, I. (2016). Commentary: what universities can learn from workplace bullying research. In H. Cowie \& C. Myers (Eds.), Bullying among university students. Cross-national 
perspectives (pp. 203-206). Abingdon, Oxon: Routledge.

Coyne, I., Craig, J., \& Chong, P. S-L. (2004). Workplace bullying in a group context. British Journal of Guidance \& Counselling, 32(3), 301-317.

Coyne, I., Farley, S., Axtell, C., Sprigg, C., Best, L., \& Kwok, O. (2017). Understanding the relationship between experiencing workplace cyberbullying, employee mental strain and job satisfaction: a dysempowerment approach. The International Journal of Human Resource Management, 28(7) 945-972.

Coyne, I., Seigne, E., \& Randall, P. (2000). Predicting workplace victim status from personality. European Journal of Work and Organizational Psychology, 9(3), 335-349.

Coyne, I., Smith-Lee Chong, P., Seigne, E., \& Randall, P. (2003). Self and peer nominations of bullying: An analysis of incident rates, individual differences, and perceptions of the working environment. European Journal of Work and Organizational Psychology, 12(3), 209-228.

Crossley, C. (2009). Emotional and behavioral reactions to social undermining: A closer look at perceived offender motives. Organizational Behavior and Human Decision Processes, 108(1), 14-24.

D’Cruz, P., \& Noronha, E. (2013). Navigating the extended reach: Target experiences of cyberbullying at work. Information and Organization, 23(4), 324-343.

Daft, R. L., Lengel, R. H., \& Trevino, L. K. (1987). Message equivocality, media selection, and manager performance: Implications for information systems. MIS Quarterly, 11(3), 355366.

Einarsen, S., Hoel, H., Zapf, D., \& Cooper, C. L. (2003). The concept of bullying at work: the European tradition. In S. Einarsen, H. Hoel, D. Zapf, \& C. L. Cooper (Eds.), Bullying and 
emotional abuse in the workplace. International perspectives in research and practice (pp. 3-30). London: Taylor and Francis.

Einarsen, S., Hoel, H., Zapf, D., \& Cooper, C. L. (2011). The concept of bullying and harassment at work: The European tradition. In S. Einarsen, H. Hoel, D. Zapf, \& C. L. Cooper (Eds.), Bullying and harassment in the workplace: Developments in theory, research and practice (2nd ed., pp. 3-40). Boca Raton, FL: CRC Press.

Einarsen, S., \& Skogstad, A. (1996). Bullying at work: Epidemiological findings in public and private organizations. European Journal of Work and Organizational Psychology, 5(2), 185-201.

Farley, S., Coyne, I., Axtell, C., \& Sprigg, C. (2016). Design, development and validation of a workplace cyberbullying measure, the WCM. Work \& Stress, 30(4), 293-317.

Farley, S., Coyne, I., Sprigg, C., Axtell, C., \& Subramanian, G. (2015). Exploring the impact of workplace cyberbullying on trainee doctors. Medical Education, 49(4), 436-443.

Ford, D. P. (2013). Virtual harassment: media characteristics' role in psychological health. Journal of Managerial Psychology, 28(4), 408-428.

Forssell, R. (2016). Exploring cyberbullying and face-to-face bullying in working life Prevalence, targets and expressions. Computers in Human Behavior, 58, 454-460.

Gardner, D., O’Driscoll, M., Cooper-Thomas, H. D., Roche, M., Bentley, T., Catley, B., ... Trenberth, L. (2016). Predictors of workplace bullying and cyber-bullying in New Zealand. International Journal of Environmental Research and Public Health, 13(5), 448-462.

Giumetti, G. W., McKibben, E. S., Hatfield, A. L., Schroeder, A. N., \& Kowalski, R. M. (2012). Cyber incivility @ work: The new age of interpersonal deviance. Cyberpsychology, Behavior, and Social Networking, 15(3), 148-154. 
Harvey, M. G., Heames, J. T., Richey, R. G., \& Leonard, N. (2006). Bullying: from the playground to the boardroom. Journal of Leadership \& Organizational Studies, 12(4), 111.

Hauge, L. J., Skogstad, A., \& Einarsen, S. (2007). Relationships between stressful work environments and bullying: Results of a large representative study. Work \& Stress, 21(3), 220-242.

Heatherington, W., \& Coyne, I. (2014). Understanding individual experiences of cyberbullying encoutered through work. International Journal of Organizational Theory and Behavior, 17(2), 163-192.

Hershcovis, M. S. (2010). “Incivility, social undermining, bullying . . oh my !”: A call to reconcile constructs within workplace aggression research. Journal of Organizational Behavior, 32, 499-519.

Hoel, H., Cooper, C. L., \& Faragher, B. (2001). The experience of bullying in Great Britain: The impact of organizational status. European Journal of Work and Organizational Psychology, 10(4), 443-465.

Hoel, H., Cooper, C. L., \& Faragher, B. (2004). Bullying is detrimental to health, but all bullying behaviours are not necessarily equally damaging. British Journal of Guidance \& Counselling, 32, 367-387.

Hoel, H., Glasø, L., Hetland, J., Cooper, C. L., \& Einarsen, S. (2010). Leadership styles as predictors of self-reported and observed workplace bullying. British Journal of Management, 21(2), 453-468.

Kane, K., \& Montgomery, K. (1998). A framework for understanding dysempowerment in organizations. Human Resource Management, 37(34), 263-275. 
Kivimaki, M., Elovainio, M., \& Vahtera, J. (2000). Workplace bullying and sickness absence in hospital staff. Occupational and Environmental Medicine, 57(10), 656-660.

Kock, N. (2004). The psychobiological model: Towards a new theory of computer-mediated communication based on Darwinian evolution. Organization Science, 15(3), 327-348.

Lewis, D. (2004). Bullying at work: the impact of shame among university and college lecturers. British Journal of Guidance and Counselling, 32(3), 281-299.

Lim, V. K. G., \& Teo, T. S. H. (2009). Mind your E-manners: Impact of cyber incivility on employees’ work attitude and behavior. Information \& Management, 46(8), 419-425.

Lutgen-Sandvik, P., Tracy, S. J., \& Alberts, J. K. (2007). Burned by bullying in the American workplace: Prevalence, perception, degree and impact. Journal of Management Studies, 44(6), 837-862.

Nielsen, M. B., Matthiesen, S. B., \& Einarsen, S. (2010). The impact of methodological moderators on prevalence rates of workplace bullying: A meta-analysis. Journal of Occupational and Organizational Psychology, 83(4), 955-979.

Nielsen, M. B., Skogstad, A., Matthiesen, S. B., Glasø, L., Aasland, M. S., Notelaers, G., \& Einarsen, S. (2009). Prevalence of workplace bullying in Norway: Comparisons across time and estimation methods. European Journal of Work and Organizational Psychology, 18(1), 81-101.

Notelaers, G., Witte, H. De, \& Einarsen, S. (2010). A job characteristics approach to explain workplace bullying. European Journal of Work and Organizational Psychology, 19(4), 487-504.

Parzefall, M-R., \& Salin, D. M. (2010). Perceptions of and reactions to workplace bullying: A social exchange perspective. Human Relations, 63(6), 761-780. 
Pearson, C., Andersson, L., \& Porath, C. (2005). Workplace incivility. In S. Fox \& P. E. Spector (Eds.), Counterproductive work behavior. Investigations of actors and targets (pp. 177200). Washington, DC: American Psychological Association.

Postmes, T., Spears, R. \& Lea, M. (2000). The formation of group norms in computer-mediated communication. Human Communication Research, 26, 341-371.

Privitera, C., \& Campbell, M. A. (2009). Cyberbullying: the new face of workplace bullying? Cyberpsychology \& Behavior: The Impact of the Internet, Multimedia and Virtual Reality on Behavior and Society, 12(4), 395-400.

Rayner, C., \& Cooper, C. L. (2006). Workplace bullying. In E. K. Kelloway, J. Barling, \& J. J. Hurrell (Eds.), Handbook of Workplace Violence (pp. 121-145). Thousand Oaks, CA: Sage Publications.

Richman, J. A., Rospenda, K. M., Flaherty, J. A., \& Freels, S. (2001). Workplace harassment, active coping, and alcohol-related outcomes. Journal of Substance Abuse, 13(3), 347-66.

Salin, D. (2001). Prevalence and forms of bullying among business professionals: A comparison of two different strategies for measuring bullying. European Journal of Work and Organizational Psychology, 10(4), 425-441.

Salin, D. (2003). Ways of explaining workplace bullying: A review of enabling, motivating and precipitating structures and processes in the work environment. Human Relations, 56(10), $1213-1232$.

Samnani, A-K. (2013). “Is this bullying?” Understanding target and witness reactions. Journal of Managerial Psychology., 28(3), 290-305.

Saunders, P., Huynh, A., \& Goodman-Delahunty, J. (2007). Defining workplace bullying behaviour professional lay definitions of workplace bullying. International Journal of Law 
and Psychiatry, 30(4-5), 340-354.

Siegel, J., Dubrovsky, V., Kiesler, S., \& Mcguire, T. (1986). Group processes in computermediated communication. Organizational Behavior and Human Decision Processes, 37, 157-187.

Snyman, R., \& Loh, J. (2015). Cyberbullying at work: The mediating role of optimism between cyberbullying and job outcomes. Computers in Human Behavior, 53, 161-168.

Spears, R., \& Lea, M. (1994). Panacea or panoptica? The hidden power in computer-mediated communication. Communication Research, 21(4), 427-459.

Spratlen, L. (1995). Interpersonal conflict which includes mistreatment in a university workplace. Violence and Victims, 10(4), 285-297.

Sticca, F., Ruggieri, S., Alsaker, F., \& Perren, S. (2013). Longitudinal risk factors for cyberbullying in adolescence. Journal of Community and Applied Social Psychology, 23, 52-67.

Strandmark, M. K., \& Hallberg, L. R. (2007). The origin of workplace bullying: experiences from the perspective of bully victims in the public service sector. Journal of Nursing Management, 15(3), 332-341.

Suler, J. (2004). The online disinhibition effect. Cyberpsychology \& Behavior: The Impact of the Internet, Multimedia and Virtual Reality on Behavior and Society, 7(3), 321-326.

Tepper, B. J. (2000). Consequences of abusive supervision. The Academy of Management Journal, 43(2), 178-190.

Vranjes, I., Baillien, E., Vandebosch, H., Erreygers, S., \& De Witte, H. (2017). The dark side of working online: Towards a definition and an Emotion Reaction Model of workplace cyberbullying. Computers in Human Behavior, 69, 324-334. 
Weatherbee, T. G., \& Kelloway, E. K. (2006). A case of cyberdeviancy: CyberAggression in the workplace. In E. K. Kelloway, J. Barling, \& J. J. Hurrell (Eds.), Handbook of Workplace Violence (pp. 445-487). Thousand Oaks, CA: Sage Publications.

West, B., Foster, M., Levin, A., Edmison, J., \& Robibero, D. (2014). Cyberbullying at work: In search of effective guidance. Laws, 3(3), 598-617.

Whitty, M., \& Carr, A. (2006). New rules in the workplace: Applying object-relations theory to explain problem Internet and email behaviour in the workplace. Computers in Human Behavior, 22(2), 235-250.

Willard, N. E. (2007). The authority and responsibility of school officials in responding to cyberbullying. The Journal of Adolescent Health, 41(6), S64-S65.

Wolak, J., Mitchell, K. J., \& Finkelhor, D. (2007). Does online harassment constitute bullying? An exploration of online harassment by known peers and online-only contacts. Journal of Adolescent Health, 41, 851-858.

Zapf, D., \& Einarsen, S. (2001). Bullying in the workplace: Recent trends in research and practice - an introduction. European Journal of Work and Organizational Psychology, 10(4), 369-373.

Zapf, D., \& Einarsen, S. (2003). Individual antecedents of bullying. In S. Einarsen, H. Hoel, D. Zapf, \& C. L. Cooper (Eds.), Bullying and emotional abuse in the workplace. International perspectives in research and practice (pp. 165-184). London: Taylor and Francis.

Zhang, S., \& Leidner, D. (2014). Workplace cyberbullying: The antecedents and consequences. Paper presented at the $20^{\text {th }}$ Americas Conference on Information Systems, Social-Technical Issues and Social Inclusion Track. Savannah 